\title{
SUMIENIE I DOBRO MORALNE
}

\section{Rozpoznanie wstępne}

1.1 Sumienie wyzwala sprzeczne opinie. Dla jednych jest zsekularyzowanym reliktem przeszłości. Inni z kolei, mimo jego marginalizacji, postrzegają sumienie jako wciąż pożyteczną instancję w moralnej praxis. Dla jeszcze innych "sumienie wciąż pozostaje i zawsze będzie jedyną instancją spójną z naszymi demokratycznymi społeczeństwami"1. Istnieją również symptomy, które wskazują na niemal zupełną utratę zaufania do teoretycznej nośności i praktycznej użyteczności tego pojęcia. Wobec kryzysu etyki i moralności, Victor Frankl dostrzega w sumieniu skuteczną pomoc w rozwiązywaniu konfliktów moralnych.

W czasach, gdy przykazania dekalogu utraciły swą niepowtarzalną wartość, każdego dnia - przekonuje Frankl - musimy przestrzegać dziesięciu tysięcy przykazań wynikających z dziesiątków tysięcy niepowtarzalnych sytuacji, które składają się na nasze życie i w odniesieniu do nich mamy obowiązek polegać na własnym sumieniu. Żywe i czułe sumienie to dla człowieka także jedyny ratunek przed skutkami egzystencjalnej pustki, a mianowicie konformizmem i totalitaryzmem².

Wydaje się, że kategoria sumienia ma niewykorzystany potencjał moralny. Zatem zarówno marginalizacja, jak i symptomy kryzysu sumienia nie zamykają drogi do myślenia o jego rehabilitacji³ a także o przydatności tej

1 P. Valadier, Pochwała sumienia, tłum. M. Żerańska, Warszawa 1997. s. 5.

2 V. Frankl, Wola sensu. Założenia i zastosowania logoterapii, tłum. A. Wolnicka, Warszawa 2010, s. 89.

${ }^{3}$ S. Hubsch, Philosophie und Gewissen. Beitrage zur Rehabilitierung des philosophischen Gewissen, Goettingen 1995. 
kategorii w sytuacjach wyboru i w realizacji moralnego dobra. Kryzys bowiem, według Barbary Skargi, może być sytuacją przesilenia i wydobywania nowych możliwości ${ }^{4}$.

1.2 Troska o dobro moralne w kulturze Zachodu sięga czasów przedfilozoficznych, a w dojrzałej formie filozoficznej - czasów Sokratesa, Platona i Arystotelesa. Nie inaczej jest współcześnie: człowiek szuka dobra, dobra pragnie i pożąda, ale też rozpoznane dobro gubi. Etyka mówi o modalności dobra moralnego. Wyróżnia przy tym trzy formy istnienia dobra moralnego: (1) dobro w postaci podstawowych norm, zasad i zobowiązań; (2) dobro w postaci działania moralnego (najbliżej stanu realnej możliwości) oraz (3) dobro w postaci zdolności moralnej osoby, które faktycznie nie wychodzi poza stadium tego, co możliwe. Gdy mówić o związkach dobra moralnego i sumienia, to niewątpliwie refleksja odwoływać się będzie do każdej z wymienionych modalności. Zainteresowanie dobrem moralnym nie jest rzeczą przypadku. W filozofii moralnej istnieje zróżnicowana argumentacja, która wskazuje na jego znaczenie. Zdaniem niemieckiego filozofa Wilhelma Vossenkuhla, „dobro moralne jest nieodzowne dla stabilności dobrego życia, dla jego trwania oraz dla ogólniejszej (i każdemu z osobna otwartej) dostępności, jako element, który chociaż jest najmniejszy, najmniej uchwytny, ale [...] decydujący i skuteczny" 5 . Zatem do żywotnych należy kwestia, czym motywowane jest rozpoznanie i realizacja dobra moralnego.

1.3 Egzystencja sytuuje człowieka wobec wielości dóbr, spośród których "zmuszany jest" on do nieustannego wybierania. Wszak - jak mówi Władysław Tatarkiewicz - życie jest stałym podejmowaniem decyzji ${ }^{6}$. W wyborach o charakterze moralnym jako oczywistość nasuwa się możliwość motywacyjna sumienia. Można przyjąć istnienie swoistego związku sumienia i dobra moralnego. Relacja między dobrem moralnym a sumieniem stanie się przedmiotem szczegółowej analizy. Przyjęcie optyki synejdezjologicznej wymaga założenia, iż sumienie wciąż jest wartościową instancją w filozofii moralnej. Zatemsumienie jawi się jako znaczący moralnie motyw rozpoznania i realizacji dobra moraln e g o. Naszym celem jest wykazanie, jak/w jakim zakresie jest to możliwe. Inaczej rzecz ujmując - jak możliwe jest dobro moralne w odwołaniu do

${ }^{4}$ Zob. B. Skarga, Granice historyczności, Warszawa 2005. s. 281.

${ }^{5}$ W. Vossenkuhl, Możliwość dobra. Etyka w XXI wieku, tłum. K. Rynkiewicz, Kraków 2012,

${ }^{6}$ W. Tatarkiewicz, Obrachunek $i$ nakazy, uczciwość i dobroć, [w:] idem, Pisma z etyki $i$ teorii szczęścia, Wrocław - Warszawa - Kraków 1992, s. 62. 
sumienia? Są to równocześnie pytania o współczesną wiarygodność sumienia. Rozważać będziemy funkcjonowanie sumienia jako motywatora procesów wyboru i urzeczywistniania dobra moralnego.

Analizy będą prowadzone w następujących kierunkach:

1. Wybrane aspekty obecności dobra moralnego.

2. Synejdezjologiczne uwarunkowania procesów wyboru dobra moralnego.

3. Sumienie jako motyw rozpoznania i urzeczywistniania dobra moralnego.

\section{Niektóre aspekty obecności dobra moralnego}

Namysł nad dobrem moralnym w filozofii sprawia od wieków trudności. Warto tutaj przywołać chociażby trzy kwestie: (1) poszukiwanie istoty dobra moralnego; (2) określenie jego funkcji oraz (3) kwestię relacji między dobrem moralnym a dobrym życiem. O modusach obecności dobra moralnego była już mowa.

2.1 Już na pytanie o status i istotę dobra moralnego trudno odpowiedzieć jednoznacznie. Na początek trzeba uznać, że dobro moralne jest zasadniczo efektem wolnego i świadomego wyboru i działania osoby, a manifestuje się w czynie. Rozpoznanie dobra i podjęte działanie winny być zgodne z przyjętym przez grupę społeczną porządkiem moralnym, jak również z sumieniem (czyn moralnie słuszny). W ten sposób moralne dobro „odnosi się do podmiotu moralnego jako takiego, jego rzeczywistego pragnienia i woli, by podążać za dobrem/wartością i je urzeczywistniać"7.

Refleksja filozoficzna zmierza w kierunku określenia warunków, które są konieczne, by dobro moralne odróżnić od innych rodzajów dobra. Poszukiwanie istoty dobra moralnego ogniskowało uwagę na rozumności i autonomiczności moralnych wyborów człowieka. Wskazuje się przy tym, że istotą dobra moralnego (czynu) jest bezinteresowność i niezależność motywacji działania; niezależność od skłonności podmiotu moralnego, od socjologicznie uwarunkowanych obyczajów i sposobów wartościowania.

Halina Promieńska w swoich badaniach dochodzi do następującej konkluzji:

7 T. Grzywacz, Dobro moralne a autentyczna realizacja człowieka, „Horyzonty Wychowania” 2005, nr 4(7), s. 61. 
[...] kwintesencją dobra moralnego w tym ujęciu jest „kosmopolityzm intencjonalny” tej wartości lub - jeśli ktoś woli - postulat traktowania elementarnych norm moralnych jako norm ogólnoludzkich, przekraczających wszelkie podziały i nierówności tradycją kulturową i polityczną utrwalone ${ }^{8}$.

2.2 Jakie funkcje spełnia dobro moralne? Zacznijmy od szerszego kontekstu. „Dobro moralne - podkreśla Wilhelm Vossenkuhl - jest istotnym elementem dobra, ponieważ tworzy powiązania między częściami dobra i nadaje im spoistość. Ogólnie mówiąc, moralne dobro jest spoiwem dobra" 9 . Dobro w postaci podstawowych norm, zasad i zobowiązań - zdaniem Promieńskiej - stanowi istotną przesłankę dokonywania wyborów, formułowania ocen moralnych czy też inspirowania działań moralnych. Trudności $\mathrm{z}$ definiowaniem dobra mogą się wiązać $\mathrm{z}$ jego wieloaspektowością. Dobro moralne jest ważne pierwszoplanowo. $\mathrm{W}$ perspektywie dobra moralnego podlegają ocenie zarówno cele działania, jak też warunki formalne czynu słusznego moralnie ${ }^{10}$.

2.3 Kolejną podejmowaną kwestią jest relacja między dobrem moralnym a dobrym życiem. Zarówno pytania o dobro moralne, jak i pytanie o dobre życie należą do etyki tak starożytnej, jak też współczesnej. W tej ostatniej obecne jest żywe - przytoczone już powyżej - przekonanie Vossenkuhla, że „dobro moralne jest nieodzowne dla stabilności dobrego życia"11. Dobre życie nie jest możliwe bez dobra moralnego. A dobro moralne z kolei jawi się jako „pewna siła, która potrafi łączyć w dobrym życiu wiele rodzajów dobra, również dobra częściowo sprzeczne"12.

Tak jest w myśli współczesnej. A sięgając do starożytnej filozofii moralnej, Pierre Hadot, znany jej interpretator, pisze, że poszukiwanie dobra, w znaczeniu możliwości dobrego życia, już od filozofii antycznej cieszyło się i nadal cieszy sporym zainteresowaniem ${ }^{13}$. Myśl starożytna wniosła ideę troski o siebie, która to idea kształtowała sposób myślenia i działania moralnego. Współcześnie kwestię tę ożywił Michael Foucault, który wskazał na wielość „technik" troski o siebie, a wśród nich rozrachunek z przeżytego

${ }^{8}$ H. Promieńska, Dobro wspólne, dobro indywidualne i dobro moralne, [w:] Dobro wspólne, red.

D. Probucka, Kraków 2010, s. 18.

${ }^{9}$ W. Vossenkuhl, op. cit., s. 282.

${ }^{10}$ Por. H. Promieńska, op. cit., s. 13-18.

11 W. Vossenkhul, op. cit., s. 281.

12 Ibidem, s. 292.

13 Por. P. Hadot, Czym jest filozofia moralna?, tłum. P. Domański, Warszawa 2000, s. 223 i nast.; a także: idem, Filozofia jako ćwiczenie duchowe, tłum. P. Domański, Warszawa 2003, s. 287 i nast. 
dnia w odwołaniu do sumienia ${ }^{14}$. Wątek ten wart jest podkreślenia z perspektywy przyjętej tezy o sumieniu filozoficznym jako znaczacym moralnie motywie rozpoznania i realiz a cji dobra moralnego. Możliwość dobra w postaci dobrego moralnie życia to przecież nie tylko teoria. Już bowiem „dobro samo pobudza $\mathrm{w}$ nas pragnienie, by je osiągnąć". Jaką rolę w tych procesach może pełnić sumienie? To podstawowy dla nas problem. Samo zaś sumienie wymaga sprecyzowania statusu tej instancji.

\section{Synejdezjologiczne uwarunkowania wyboru dobra moralnego}

Proces rozpoznania i konstytuowania dobra moralnego w oparciu o sumienie, obok swoistości dobra moralnego, jest warunkowany również czynnikami synejdezjologicznymi. Warto tu podkreślić wagę następujących elementów: (1) sposób definiowania sumienia; (2) rozróżnienie między filozoficzną i religijną interpretacją sumienia; (3) tezę o marginalizacji i regresie statusu sumienia oraz (4) możliwość tezy o odnowie sumienia we współczesnym dyskursie filozoficznym.

3.1 Punktem wyjścia w pracach nad sumieniem jest przyjęcie wstępnej, najczęściej roboczej, definicji sumienia. Zadanie nie należy do łatwych, zwłaszcza że - jak piszą niektórzy - sumienie w swej podmiotowej strukturze jest niedefiniowalne. Według między innymi księdza Antoniego Siemianowskiego, „, w pierwotnych przejawach sumienie jest przeżyciem, którego istotę trudno uchwycić i trafnie nazwać; wymyka się [bowiem] wszelkim próbom zdefiniowania"15. Niemniej jednak, potrzeba choćby opisowych definicji wydaje się koniecznością. Wobec takich prób należy zachować dystans, sumienie bowiem bywa określane z perspektywy przyjętego stanowiska filozoficznego bądź antropologicznego, jako że za teorią sumienia stoi określona koncepcja człowieka. I niekoniecznie teoria sumienia oddaje wiernie fenomeny sumienia. Bywa, że filozofowie bardziej dbają o spójność własnego stanowiska niż o adekwatny obraz sumienia. W zakresie definiowania potrzebna jest roztropność.

\footnotetext{
14 Por. M. Foucault, Hermeneutyka podmiotu, tłum. M. Herer, Warszawa 2012, s. 93 i nast.

${ }^{15}$ Ks. A. Siemianowski, Sumienie stróżem ludzkiej wolności, [w:] Sumienie w świecie wolności, red. ks. J. Jagiełło, ks. Wł. Zuziak, Kraków 2007, s. 173
} 
Jednym z możliwych punktów wyjścia w analizach sumienia są potoczne intuicje dotyczące jego rozumienia i interpretacji. Tą drogą podążali między innymi Martin Heidegger czy Nikolai Hartmann. Ten ostatni, odwołując się do powszechnego doświadczenia, pisał:

Każdy rozumie przezeń wewnętrzną instancję nagany (i uznania), rodzaj wskaźnika dobra i zła, głosu, który w sposób nieoczekiwany, tajemniczy przemawia z głębi naszej własnej istoty - i to przemawia kategorycznie i przekonująco - aczkolwiek $\mathrm{w}$ opozycji do naturalnej samoakceptacji ${ }^{16}$.

Tekst ten nie wyczerpuje znamion definicji, a raczej wprowadza w problematykę sumieniową i otwiera na dalsze poszukiwania. Natomiast na potrzeby niniejszego artykułu przyjmujemy następującą definicję opisową: Sumienie jest specyficznym uzdolnieniem czlowieka o charakterze psychiczno-moralnym. Przejawia się w sferze psychicznej jako ból, wyrzut (sumienia) lub poczucie powinności, odsłaniając przy tym stosunek osoby do dobra i zła. Działa instynktownie lub refleksyjnie, adekwatnie do świadomości moralnej, zespołu zinternalizowanych wartości oraz indywidualnej wrażliwości.

3.2. Geneza sumienia, zwłaszcza w tej postaci, która współcześnie dominuje, wskazuje na średniowieczną sublimację filozoficznych wątków starożytności i chrześcijańskich wątków religijnych. Dla niektórych religijne uwarunkowanie sumienia jest istotną przeszkodą $\mathrm{w}$ zajmowaniu się tą instancją. Uznanie sumienia za kategorię wyłącznie religijną oznacza, że pozbawiamy się możliwości, jakie daje sumienie filozoficzne. Bliższe nam jest stanowisko, które opowiada się za sumieniem filozoficznym, to jest takim, które jego genezę, strukturę, funkcje i naturę wyjaśnia na drodze filozoficznej.

Podział na sumienie religijne i sumienie świeckie znakomicie opisała Hannah Arendt. Zarówno dzieje sumienia, jak i kultura moralna Zachodu uzasadniają ten podział. Przyjęte rozróżnienie wprowadza jasność metodologiczną i pozwala unikać skutków niektórych sporów o naturę/funkcjonowanie sumienia. Tym bardziej że współcześnie również etycy chrześcijańscy są zdania, że tak jak „pojęcie osobowego Boga nie jest nierozerwalnie związane $\mathrm{z}$ doświadczeniem wartości moralnych, [tak] głos sumienia nie zakłada znajomości osobowego Boga"17. Stanowisko to podziela psycholo-

16 N. Hartmann, O istocie wartości etycznych, tłum. J. Filek, „Logos i Ethos” 1993, nr 2, s. 196-197.

${ }^{17}$ D. von Hildebrand, Christian Ethics, [cyt. za:] B.R. Brandt, Etyka. Zagadnienia etyki normatywnej i metaetyki, tłum. B. Stanosz, Warszawa 1996, s. 113. 
gia, której zdaniem dyskusja o wrażliwości sumienia nie musi być warunkowana światopoglądowo ${ }^{18}$. Tego samego zdania jest współczesna filozofia moralności, która przekonuje, iż współczesne interpretacje sumienia niekoniecznie wymagają założeń metafizycznych ${ }^{19}$. Warto $\mathrm{w}$ tym miejscu przywołać argumentację Tadeusza Kotarbińskiego w odniesieniu do podstaw etyki religijnej i etyki świeckiej. Filozof troszczył się o to, aby utrata wiary nie pociągała za sobą zachwiania podstawami etyki. Religijne interpretacje sumienia po utracie wiary niekoniecznie niwelują wyrzuty sumienia czy poczucie powinności. Inne natomiast będą odniesienia aksjologiczne, do których sumienie się odwołuje. Inaczej również będą rozłożone akcenty interpretacyjne i motywacyjne moralności.

Podkreślmy to jednak, że metodologia również szanuje odrębność sumień - filozoficznego i religijnego. Ale też z właściwą sobie wnikliwością dostrzega antropologiczną płaszczyznę wspólnoty badań. Samo zaś sumienie jest zarówno problemem religijnym, jak i filozoficznym, ale najpierw problemem antropologicznym. A zatem $\mathrm{w}$ rozważaniach posłużymy się głównie sumieniem filozoficznym.

3.3. Jeśli sumienie wciąż jawi się jako znaczący moralnie motyw rozpoznania i urzeczywistniania dobra moralnego, to należy przyjrzeć się procesom dotykającym wprost sumienia, zwłaszcza w jego funkcji realizacji dobra moralnego. Współczesna filozofia porusza tę kwestię, formułując dwie sprzeczne ze sobą tezy. Pierwsza mówi o regresie i marginalizacji sumienia. Druga o możliwościach odnowy tej instancji we współczesnym dyskursie filozoficznym. Wskazuje to na przeciwstawne tendencje, którym podlega sumienie zaangażowane $\mathrm{w}$ dobro moralne. Rozważmy je kolejno, by podkreślić złożoność relacji sumienia i dobra moralnego. Bowiem to, jaką funkcję przydzielimy sumieniu w tej relacji, zależy od rozpoznania jego statusu.

Współczesność postindustrialna niesie nowy typ działań, które wykraczają zasięgiem, przestrzenią, czasowością, skomplikowaniem związków przyczynowo-skutkowych poza możliwości indywidualnego sumienia. Trudno się temu dziwić, skoro nawet wąskie specjalizacje naukowe nie dostarczają przesłanek do oceny moralnej wielu działań, które miałyby podlegać ocenie. Co więcej - faktyczna dysproporcja między zwielokrotnioną mocą destrukcyjnych skutków stosowania nowych technik i technologii

18 Por. W.G. Allport, Osobowość i religia, tłum. A. Bartkowicz, I. Wyrzykowska, Warszawa 1988 , s. 58-62. 2001.

19 Por. R. Spaemann, Osoby. O różnicy między czymś a kimś, tłum. J. Merecki, Warszawa 
a możliwościami teorii etycznych i charakterem zasobów moralnych człowieka musi budzić niepokój.

Dysproporcja wpływająca na zachwianie równowagi systemowej między tym, co technicznie możliwe, a tym, co etycznie dopuszczalne czy moralnie powinne, wskazuje na konieczność radykalnego wzmocnienia ogniwa słabszego [w tym układzie przyp. A.A.D.], jakim jest sumienie ludzkie ${ }^{20}$.

Podkreślmy, że współcześnie o sumieniu pisze się raczej mało. Większość etyków i filozofów uznaje to pojęcie za zbyt staroświeckie, aby mogło być używane akademicko. Sumienie jest fenomenem bardzo osobistym. Z sumieniem trudno wyjść na agorę. Społecznie bardziej ceni się cnoty instrumentalne: skuteczność, błyskotliwość w blasku fleszów. Cnota sumienności nie odnajduje się w takiej perspektywie.

Sumienie, odpowiedzialność i dzielność podmiotu przeciwstawiającego się przemożnym niekiedy okolicznościom zostają zastąpione systemem zabezpieczeń społecznych w postaci kodeksu postępowania i sankcji. Ginie osobowy aspekt postępowania moralnego decydujący o sensie życia i stopniu rozwoju duchowego ${ }^{21}$.

Niekorzystne tendencje dla statusu sumienia w etyce i moralności wzmacnia fakt, iż we współczesnej filozofii moralnej prym wiodą utylitaryzm, neokantyzm oraz etyka cnót. Spośród nich najbliższa sumieniu jest etyka cnót. Obecności sumienia nie sprzyjają również niektóre zjawiska w metaetyce, np. rozdzielenie sfery kognitywno-poznawczej i psychologiczno-empirycznej. W rezultacie dyskurs sumieniowy staje się kłopotliwy, bo nie spełnia wymogu racjonalności. Podsumowując, powoływanie się na sumienie, w perspektywie tezy o jego kryzysie i marginalizacji, skłania do ostrożności przy formułowaniu końcowych wniosków.

3.4. Przeciwwagę dla tezy o marginalizacji i regresie sumienia stanowi teza o rehabilitacji i możliwości odnowy tej instancji. Jest pewną prawidłowością, że w okresach przełomów kulturowych (a z takim pewnie mamy do czynienia), przy burzeniu starych struktur ładu i tworzeniu nowych jego form, nabiera znaczenia autonomia myślowa i moralna jednostki. Jak podkreśla francuski filozof Paul Valadier, autor książki Pochwała sumienia, kiedy nie sprawdzają się dawne struktury regulacyjne (normy i zasady etyczne)

${ }^{20}$ H. Promieńska, Czy starożytna myśl etyczna zachowuje swa ważność wspótcześnie?, [w:] Etyka wobec problemów wspótczesnego świata, red. H. Promieńska, Katowice 2003, s. 69.

${ }^{21}$ K. Sosenko, Ekonomia w perspektywie aksjologicznej, Kraków 1998, s. 121. 
i dawne formy organizacji życia społecznego, jednostka staje wobec nich sama ze swoim sumieniem ${ }^{22}$, co nie powinno zaskakiwać.

Do autonomii moralnej jednostki i do świadomości moralnej (czytaj: sumienia) odwoływano się zarówno w epoce upadku greckiego polis, jak i w epoce europejskiego Oświecenia. Opowiedzenie się za sumieniem przy poszukiwaniu podstaw wyboru dobra moralnego niekoniecznie jest entuzjastyczną możliwością, ale już bardziej rozsądną koniecznością. Mimo to współczesny status sumienia jest przedmiotem zainteresowania etyków różnych orientacji. Zygmunt Bauman pisze tak:

Na szczęście dla ludzkości (choć nie zawsze ku spokojowi ducha podmiotów moralnych) i na przekór operacyjnym zabiegom ekspertów, sumienie moralne - ów bodziec pierwotny wszelkich impulsów moralnych i korzeń najgłębszej moralnej odpowiedzialności - nie zostało amputowane; uległo tylko znieczuleniu. Żyje nadal, być może uśpione, a może oszołomione, a może milczące ze strachu przed wydrwieniem - ale zdolne do tego, by się przebudzić i przemówić23.

Dlatego skłonni jesteśmy podzielić opinię Leszka Kołakowskiego, który pisze: „Słuchanie sumienia jest w sumie bezpieczniejsze, ono mniej nas może oszukiwać aniżeli zasady moralne, które przecież niemal zawsze potrafimy na swoją korzyść przekręcić" 24 .

\section{Sumienie jako motyw rozpoznania i realizacji dobra moralnego}

Dotykamy newralgicznego punktu naszej refleksji, w której wyodrębnimy następujące, kolejno rozważane, elementy. Będą to: (1) społeczny wymiar obecności sumienia, (2) dobro moralne a status sumienia, (3) problem przekształcenia motywu sumienia w czyn moralnie dobry, (4) subiektywność a obiektywność sądów sumienia, (5) kryteria kierowania się własnym sumieniem, (6) sumienie błędne.

4.1 Zarówno dobro moralne, jak i sumienie odnajdują swoje miejsce w perspektywie społecznego ładu moralnego. Znany filozof moralista Richard

22 Por. P. Valadier, Pochwała sumienia, op. cit.; a także: H. Promieńska, Czy starożytna myśl..., op. cit., s. 70 . s. 339.

Z. Baumann, Etyka ponowoczesna, tłum. J. Baumann, J. Tokarska-Bakir, Warszawa 1996,

${ }^{24}$ L. Kołakowski, O sumieniu, [w:] idem, Mini wykłady o maksi sprawach, Kraków 2007, s. 184. 
B. Brandt podkreśla jednak, że nie jest ważne, czy ład ten motywowany jest nakazami moralnymi, sumieniem, wrażliwością na opinię publiczną, czy w odwołaniu do osobistych ideałów. Ważne jest, że ludzie postępują w zgodzie z pewnymi regułami, które niosą społeczny porządek ${ }^{25}$. Wstępnie wydawać by się mogło, że sumienie niesie $\mathrm{z}$ sobą większą pewność moralną w osiąganiu dobra. Tak jednak nie jest. A samo „kierowanie się sumieniem nie jest tym samym, co kierowanie się nakazami moralnymi tout court. Jest to zawsze odwoływanie się do moich własnych, przeze mnie sformułowanych dyrektyw postępowania, niezależnie od tego, co jest [ostatecznie - przyp. A.A.D.] źródłem ich autorytetu: może to być autorytet innej osoby, boskie prawo czy pewna ideologia" 26 .

Mimo to, odwoływanie się do sumienia nadal wydaje się znaczącym motywem urzeczywistniania moralnego dobra, choć z wieloma zastrzeżeniami. Indywidualne sumienia nie dają możliwości zbudowania społecznego ładu moralnego, choćby z uwagi na to, że sumienia te są różne w zakresie wrażliwości moralnej czy też w przeżywaniu moralnego dobra. Zobaczmy zatem, czego, opierając się na sumieniu, można oczekiwać $\mathrm{w}$ perspektywie moralności indywidualnej.

4.2 Jesteśmy w punkcie rozważań, który wymaga odpowiedzi na pytanie o współczesny status sumienia. Jeśli sumienie ma być interpretowane jako motyw dobra moralnego, to zależy nam, by rozpoznać i przybliżyć procesy, które się w nim dokonują. Chodzi o procesy, które prowadzą od motywu sumienia do czynu dobrego moralnie. W analizie zawiera się również metaproblemowa kwestia możliwości zbadania samego sumienia.

I tutaj pojawia się problem: filozofia moralna twierdzi, iż nie jest możliwe zbadanie sumienia $\mathrm{z}$ uwagi na jego podmiotowe i indywidualne zakorzenienie. Według zasady egzystencjalistycznej, „podmiotowe jakości przeżyć są niekomunikowalne $\mathrm{w}$ czasie teraźniejszym, można je co najwyżej opisać ex post" ${ }^{27}$. Przeżycia moralne związane z sumieniem są niedostępne dla badacza z zewnątrz, lecz znane jedynie z autopsji, pierwszoosobowo. $\mathrm{W}$ tym sensie indywidualne sumienie jest strukturą nieczytelną i całkowicie niedostępną dla innych. To stwarza poważne trudności w rozpoznaniu sumienia jako motywu urzeczywistniania moralnego dobra. Zachodzi także różnica między tezą o takiej możliwości a racjonalnym opisem tego wewnętrznego procesu.

25 Por. R.B. Brandt, op. cit., s. 150-154.

26 J. Górnicka-Kalinowska, Idea sumienia w filozofii moralnej, Warszawa 1999, s. 21.

27 Ibidem. 
A przecież - z drugiej strony - specyfika sumienia ,jako instancji gwarantującej [...] słuszność decyzji polega właśnie na tym, iż reprezentuje ono ponadpodmiotową i ponadindywidualną obiektywność $\mathrm{w}$ dziedzinie moralnych wzorców i norm postępowania" 28 . Warto przyjrzeć się następującej sugestii: panuje zgodność co do tego, że sądy sumienia cieszą się statusem pewności moralnej, czyż jednak nie oczekujemy wyjaśnienia, co jest źródłem tego przekonania? Racje sumienia są subiektywne, choć z perspektywy osoby/podmiotu są zawsze obiektywne. I nie rzecz $\mathrm{w}$ tym, by spierać się o przydatność sumienia przy urzeczywistnianiu dobra moralnego, ale o zrozumienie, czy i w jakim stopniu filozof-etyk może sumieniu zaufać, a procesy owe uczynić racjonalnymi.

W filozofii moralnej podejmowane są różne próby zrozumienia wymienionych procesów. Można dokonać rekonstrukcji języka uzasadnień czy analizy fenomenologicznego opisu przeżyć sumienia. Można również, jak czyni to Józef Tischner, zinterpretować kwestię z pozycji własnego stanowiska synejdezjologicznego. Tischner rzuca światło na relacje między dobrem, dobrą wolą, sumieniem a próbą realizacji dobra. Jego rozważania odnoszą się do procesów zogniskowanych wokół sumienia. Filozof przekonuje:

Dobra wola oznacza pragnienie dobra. Ale pragnienie dobra byłoby ślepe, gdyby nie zmysł moralny, który otwiera wolę na to, co dobre [...]. Z kolei, bez sumienia widzenie i pragnienie dobra kończyłoby się samym podziwem dla dobra, bez próby realizacji ${ }^{29}$.

Interpretacja zatrzymuje się jednak na progu procesów konstytuowania się dobra moralnego. Chcemy wiedzieć, jak to się dzieje, że sumienie niesie możliwość samorealizacji osoby na podstawie dobra moralnego. Jednak nie wynika z tego możliwość rozpoznania ani kontrolowania tych procesów.

Jak zatem rozumieć rolę sumienia? Otóż sąd sumienia jako motyw decyduje o dobroci podejmowanego czynu. Według Joanny Górnickiej-Kalinowskiej, „imperatywność sumienia powoduje, iż jesteśmy najzupełniej przekonani, iż nasz wybór jest prawidłowy i najbliższy obiektywnemu dobru. Z pozycji osoby przeżywającej akty sumienia są one zawsze wypełnieniem dobra rzeczywistego i obiektywnego" ${ }^{\prime 30}$.

${ }^{28}$ Ibidem, s. 17 i 25.

${ }^{29}$ J. Tischner, Etyka wartości i nadziei, [w:] D. von Hildebrand [et al.] Wobec wartości, Poznań 1984, s. 100.

${ }^{30}$ J. Górnicka-Kalinowska, op. cit., s. 22. 
4.2 W jaki sposób motyw sumienia przekształcić w czyn moralnie dobry? Dobro moralne może być wybierane i urzeczywistniane $\mathrm{w}$ odniesieniu do różnych motywów. Jednym $\mathrm{z}$ nich niezmiennie pozostaje motyw sumienia. W jakim jednak sensie można zasadnie mówić, iż akt sumienia prowadzi do wyboru dobra moralnego? Czym ten proces może być warunkowany? To trudne pytania, jeśli zważyć na fakt, że żadna z prób, także fenomenologicznych, nie dała wglądu w to, co dzieje się w sumieniu. Nie udało się bowiem, niestety:

pokazać tak istotnego dla etyki i dla tzw. teorii działania przekształcenia rzeczywistych ciągów myślowych w ciągi motywacyjne, tych zaś w sekwencję faktów i zachowań. „Czarna skrzynka” intencji, motywów i decyzji okazała się nieprzenikniona zarówno dla etyków i teoretyków działania orientacji behawiorystycznej (np. D. Richards), których wiedza ogranicza się w istocie do tego, co ludzie mówią i jak postępują - jak i dla filozofów wspierających się na hipotezach, których nie sposób sprawdzić31.

Stąd skazani jesteśmy na twierdzenia ogólne typu: „Dobro [moralne przyp. A.A.D.] konstytuuje się $\mathrm{w}$ osądach dokonywanych przez moralną świadomość (sumienie) podmiotu"32. Niemożliwość analitycznego odtworzenia procesów, które dzieją się w sumieniu, prowadzi do stawiania hipotez $w$ tym zakresie i do ich koniecznej weryfikacji.

Relacja dobra moralnego i sumienia prowadzi do innych jeszcze intuicji. W kontekście sumienia pytamy: kiedy czyn jest moralnie dobry?, i odpowiadamy: czyn jest dobry nie ze względu na "skutek mierzony na skali «obiektywnego dobra», lecz ze względu na motyw, czyli głos sumienia"33. Bowiem istota związku sumienia i dobra nie leży w tak zwanej „odległości” od zespołu norm, do którego odwołuje się sumienie, lecz w głębi ich akceptacji i uznania przez podmiot za własne. Jak widać, nie znaleźliśmy odpowiedzi na pytanie, jak motyw sumienia przekształcony zostaje w czyn moralnie dobry.

4.3 Skoro nie mamy wglądu w samo sumienie, odwołujemy się do wiedzy o sądach sumienia. Mówimy, że sądy sumienia mają charakter subiektywny, ale jednocześnie wychwytujemy napięcie między dążeniem do obiektywizacji norm a ich subiektywnym statusem w sumieniu (w świadomości moralnej). Kwestię tę rozjaśnia Robert Spaemann, który pisze:

\footnotetext{
31 Ibidem, s. 44

32 T. Grzywacz, op. cit., s. 61.

33 Por. J. Górnicka-Kalinowska, op. cit., s. 26.
} 
„W sumieniu to, co ogólne, obiektywny porządek dóbr i powinności dostosowania się doń, zaczyna obowiązywać jako nasze chcenie. Sumienie jest wymaganiem, które sami sobie stawiamy" 34 . I nie może być dla osoby dobra w ogóle, jeśli to, co obiektywnie słuszne i dobre, nie zostanie subiektywnie uznane przez sumienie za słuszne. To jest określona, aczkolwiek krucha, podstawa, do której możemy się odwołać przy relacji sumienie - dobro moralne.

Według Spaemanna, "tym, ku czemu kierujemy się w sumieniu, jest pełna obiektywność i absolutność: nie to, co wydaje się nam dobre, lecz to, co dobre samo w sobie, co tu i teraz winniśmy uczynić, i to, co złe, czego winniśmy zaniechać. Sąd sumienia wnosi roszczenie do ważności absolutnej"35. Nie oznacza to, jak już wiadomo, że każdy sąd sumienia tę absolutność i obiektywność odzwierciedla. W tym tkwi pewna słabość, gdy idzie o rozpoznanie relacji dobra moralnego i sumienia. Sumienie, owszem, jest absolutne z uwagi na absolutność osoby. Ale też słusznym się wydaje, że sądy sumienia na taką obiektywność wskazują.

4.4 Jeśli sumienie ma być motywem dobra moralnego, to zapytać należy: Kiedy wiadomo, że człowiek posługuje się własnym sumieniem w wyborach moralnych? Jak zweryfikować, czy ktoś kieruje się w wyborze moralnym dyrektywą sumienia? Niektórzy pytają dalej: Dlaczego człowiek nie zawsze kieruje się własnym sumieniem?

Najpełniejszą i zarazem subiektywną odpowiedzią jest orzeczenie samego podmiotu moralnego. Sumieniem kieruje się ten, kto ma przekonania moralne i „uznaje wyższość jednych wartości nad innymi, ma wyobrażenia moralne dobrych celów, nadto jego przekonania są niesprzeczne $\mathrm{z}$ jego wizją świata". Jednakże i ta epistemologiczno-normatywna podstawa nie wystarcza, by orzekać o dobru moralnym. Górnicka-Kalinowska, precyzując, dodaje: „Nasze poglądy wraz z wynikającymi zeń dyrektywami działania muszą nadto przekształcić się w motywy, ergo musimy chcieć postępować zgodnie $\mathrm{z}$ kierunkiem tych dyrektyw" 36 . Wiedza o tym ma jednak niezmiennie charakter podmiotowy (subiektywny).

W niektórych nurtach filozofii moralnej czuje się ograniczone zaufanie do instancji sumienia. Sama dyrektywa sumienia to wiele, gdy mówimy o dobru moralnym, i jednocześnie zbyt mało, by mieć pewność realizacji dobra moralnego. Mieści się w tym antropologiczna myśl o ograniczoności s. 64-65.

34 R. Spaemann, Podstawowe pojęcia moralne, tłum. P. Mikulska, J. Merecki, Lublin 2000,

${ }^{35}$ R. Spaemann, Osoby..., op. cit., s. 217.

36 Por. J. Górnicka-Kalinowska, op. cit., s. 18. 
ludzkiego bytu, a tym samym myśl o antropologicznym ograniczeniu interpretacji sumienia.

4.5 Postulat kierowania się sumieniem może być utrudniony jeszcze z innej przyczyny. Ocenę przydatności sumienia w wyborze (realizacji) dobra moralnego utrudnia fakt uznawania tak zwanego sumienia błędnego, choć w filozofii moralnej nie wszyscy przyjmują taką możliwość. Konsekwencje tezy o sumieniu błędnym są jednak daleko idące.

Godność człowieka skłania, by to, co sumienie rozpoznaje jako dobre i słuszne, nawet przy sumieniu błędnym uznać za obowiązujące. I nie ma możliwości weryfikacji takiej sytuacji. Ten fakt wpływa na ocenę statusu sumienia i wymownie mówi o całej kondycji moralnej człowieka. Jeśli zatem badacz poszukuje pewności absolutnej w sądach sumienia i moralnych wyborach, to synejdezjologia takich możliwości nie obiecuje.

Na swoistość autorytetu sumienia i charakter jego pewności wskazywał w Summie Teologicznej św. Tomasz z Akwinu, który przyjmował następujące rozumowanie: „Wiara w Chrystusa sama w sobie jest rzeczą dobrą, jednakże błędem moralnym jest wierzyć w Chrystusa, jeśli rozum mówi nam, że nie jest to dobre; każdy musi słuchać własnego sumienia, nawet jeśli to sumienie błądzi" 37 . Sumienie zatem jest instancją moralną, która niekoniecznie stanowi obiektywną gwarancję wyboru dobra moralnego. Dlatego ma rację Spaemann, gdy twierdzi, że nie ma dobra, które byłoby przeciwne sumieniu, ale nie wszystkie nakazy sumienia są dobrem. Natomiast, "jakimś znakiem, że ktoś rzeczywiście idzie za głosem sumienia, a nie za zwykłym kaprysem, jest gotowość kontrolowania jego poglądu przez porównanie z innymi, przez konfrontację"38. Możliwe jest $\mathrm{w}$ takim przypadku odwołanie do idei dialogu sumień, co proponują między innymi Jürgen Habermas, Ryszard Wiśniewski czy Krzysztof Stachewicz.

\section{Podsumowanie}

$5.1 \mathrm{~W}$ artykule postawiono następujący problem: $\mathrm{w}$ jakim zakresie/jak możliwe jest interpretowanie sumienia jako znaczącego moralnie motywu rozpoznania i realizacji dobra moralnego? Istnieją bowiem słuszne intuicje, aby wiązać dobro moralne z sumieniem. Do filozofii sumienia natomiast należy te procesy rozpoznać i racjonalnie ująć.

37 Św. Tomasz z Akwinu, S.Th., Ia IIae, q. 19, art. 5.

38 R. Spaemann, Podstawowe pojęcia moralne..., op. cit., s. 70-71. 
Analizę zasadniczą poprzedziły rozważania na temat aspektów obecności dobra moralnego oraz uwarunkowań synejdezjologicznych procesów urzeczywistniania dobra moralnego. Badania - z jednej strony - wskazały na fakt, że istnieją trudności już z samym definiowaniem dobra moralnego. Ponadto, sumienie niekoniecznie jest jedynym motywem jego realizacji. $\mathrm{Z}$ drugiej strony, pojawiła się kwestia aktualnego statusu samego sumienia. Analizy są bowiem utrudnione przez ambiwalentny stosunek filozofów moralności do kategorii sumienia, jak również poprzez rozważanie zarówno tezy o marginalizacji i kryzysie sumienia, jak i tezy o możliwości jego odnowy. Jedną z przyczyn niechęci do kategorii sumienia jest przyjmowana a priori teza, iż jest to kategoria o charakterze religijnym. W artykule oparliśmy się na dyskursie filozoficznym.

Następnie podkreślono, że sumienie jest ważnym motywem w realizacji dobra moralnego, ale już niekoniecznie możliwe jest budowanie społecznego ładu moralnego w odwołaniu do indywidualnego sumienia. Ponawiano również próby zrozumienia procesów sumienia, które wiodły od intencji, motywacji, do czynów moralne dobrych. Potoczne intuicje podkreślają taką możliwość. Jednakże uchwycenie i zracjonalizowanie (ergo: zrozumienie) tych procesów okazało się niemożliwe, a to dlatego, że indywidualne sumienie - według filozofii moralnej - jest badawczo niedostępne poza podmiotem moralnym (w pierwszej osobie). „Czarna skrzynka” intencji, motywów, decyzji i odpowiedzialności okazała się niemożliwa do zbadania. Pozostaliśmy z pytaniem: kiedy/jak czyn sumienia prowadzi do moralnego dobra? Próby odpowiedzi również miały charakter formalny, np. czyn moralnie dobry nie jest mierzony jako skutek na skali obiektywnego dobra, lecz uznany za dobro z uwagi na głos (motyw) sumienia.

Filozof-etyk niezmiennie pozostaje $\mathrm{w}$ zawieszeniu $\mathrm{z}$ pytaniem o obiektywność sądów sumienia dotyczących moralnego dobra, a także z pytaniem o pewność tychże sądów. Racje sumienia są podmiotowe (subiektywne), choć z perspektywy osoby zawsze obiektywne. Jednakże to, ku czemu kierujemy się intuicyjnie w sumieniu, określone zostało jako obiektywność dobra moralnego. Jeszcze inaczej: to, co dobre ogólnie i obiektywnie, w sumieniu zyskuje status podmiotowy, osobisty. I to jest pewien walor. Natomiast jeśli szukamy formuły dobra bezwarunkowego, która będzie podstawą codziennej praktyki moralnej, to właśnie sumienie takiej formuły dostarcza ${ }^{39}$. Jeśli szukamy formuły dobra zawsze obiektywnego i absolutnie pewnego, to takiej formuły w sumieniu nie znajdziemy.

\footnotetext{
${ }^{39}$ Por. J. Górnicka-Kalinowska, op. cit., s. 8.
} 
Na zakończenie proponujemy zwrócić myśl ku pewnym ograniczeniom antropologicznym już to samego sumienia, już to całego bytu ludzkiego, co trafnie wyraził Victor Frankl:

Sumienie jest zjawiskiem typowo ludzkim [...]. Prowadzi nas ku sensom, ale może też prowadzić na manowce. Jest to nieodłączna część kondycji człowieka. Sumienie może błądzić i nigdy nie możemy być [absolutnie - przyp. A.A.D.] pewni, że to nasze sumienie ma rację, podczas gdy sumienie innego człowieka, nakazujące mu coś całkiem przeciwnego, się myli - czy może jest dokładnie na odwrót. Sumienie nie może być ogólną/uniwersalną zasadą moralności. Może być formalną zasadą. Indywidualną zasadą. I tutaj nie znajdziemy lepszej. Nie chodzi o to, że nie ma prawdy [o dobru - przyp. A.A.D.] - jest i być może tylko jedyna. Ale nikt nie może mieć całkowitej pewności, że to on jest jej głosicielem ${ }^{40}$.

Jak widać, słuchanie głosu sumienia, w sensie absolutnie pewnej i obiektywnej podstawy wyboru dobra moralnego, nie jest oczywiste. $Z$ perspektywytezy o sumieniu filozoficznym jako znaczacym moralnie motywie wyboru i realizacji dobra mor a ln e g o ma to jednak ważne znaczenie.

Teza ta może zostać wzmocniona przez sformułowanie obowiązków względem sumienia. Mówi o tym dyrektywa Kanta, który pisze:

Obowiązkiem sumienia (ale tylko pośrednim) pozostaje tu wyłącznie dbałość o własne sumienie, tak aby ten nasz wewnętrzny sędzia przemawiał głosem czystym i donośnym, tudzież stosowanie do wszelkich dostępnych środków, które mogą sprawić, że będziemy mu posłuszni41.

Do tego należałoby dodać troskę o stabilność charakteru moralnego, czyli o podobny stosunek emocjonalny i intelektualny do przyjętego zespołu norm, do otoczenia i tak samo działającego sumienia. Natomiast w kwestii samego działania sumienia - człowiek winien umieć dostrzegać względność własnych pragnień i interesów. Tendencja dążenia do obiektywnego wyboru moralnego w oparciu o sumienie może i winna być weryfikowana przez dialog sumień o dobru i sprawiedliwości, co pozwoli budować płaszczyznę realizacji dobra moralnego we wspólnocie własnego kręgu społecznego ${ }^{42}$. Co wreszcie oznacza, że nie w każdym sądzie jest wyrażona prawda o dobru, ale w każdym sądzie sumienia owo dążenie do prawdy jest obecne.

${ }^{40}$ V.E. Frankl, Bóg ukryty. W poszukiwaniu ostatecznego sensu, tłum. A. Wolnicka, Warszawa 2012, s. 146.

${ }^{41}$ I. Kant, Metafizyka moralność, tłum. E. Nowak, Warszawa 2005, s. 269

42 Por. R. Spaemann, Podstawowe pojęcia..., op. cit., s. 65. 
5.2 Analizy relacji sumienie - dobro moralne są utrudnione, a niekiedy wręcz niemożliwe. Filozofia moralna nie jest w stanie odtworzyć procesów, jakie zachodzą $\mathrm{w}$ sumieniu. $\mathrm{W}$ tym miejscu skazani jesteśmy na hipotezy, które należy cierpliwie poddawać weryfikacji. Nie znaczy to jednak, że o wyborze i realizacji dobra moralnego nie możemy nic powiedzieć. Sąd sumienia zawsze orzeka o słuszności wyboru, lecz nie zawsze to, co słuszne, jest obiektywnie dobre. $W$ tym tkwi słabości interpretacji sumienia jako doniosłej moralnie podstawy wyboru dobra moralnego. Natomiast weryfikacją dla człowieka sumienia będzie zawsze gotowość do podejmowania odpowiedzialności za skutki wyborów i działań dokonanych zgodnie z własnym $\mathrm{z}$ sumieniem.

5.3 Funkcjonowanie sumienia $\mathrm{w}$ perspektywie dobra moralnego bez wątpienia odnajduje - z uwzględnieniem przedstawionych wyżej wątpliwości - należne tej dyspozycji miejsce w życiu moralnym człowieka. Ale czy będzie to postawa dominująca we współczesnej filozofii moralnej, to już nie jest ani pewne, ani tym bardziej oczywiste. Hipoteza o sumieniu jako absolutnej i pewnej podstawie wyboru dobra moralnego jest nie do utrzymania. Ale - przy przedstawionych $w$ wystąpieniu wątpliwościach - podważenie i zanegowanie doniosłego statusu sumienia $\mathrm{w}$ tym zakresie byłoby błędem w filozofii moralnej, a w antropologii filozoficznej odebraniem człowiekowi istotnego atrybutu jego kondycji.

\section{Conscience and Moral Good}

\section{Summary}

The article discusses the issue of the relationship between conscience and moral good. The main problem analysed in this paper takes the form of the following question: In what way can conscience be a moral motif for the realization of the moral good? As concluded, it is impossible to accept the hypothesis of conscience as the basis of absolute moral good. However, the negation of the important status of conscience in the realization of moral good would be an error in moral philosophy. In philosophical anthropology this would mean depriving human beings of the significant attribute of their condition. 